\title{
A Study on Quality of Work Life among Employees in Cairo Amman Bank
}

\section{Basman Al Dalayeen}

Faculty of Business Administration and Economics, Al-Hussein Bin Talal University, Ma'an, Jordan

Email: basman_2014@yahoomail.com

How to cite this paper: Al Dalayeen, B. (2017). A Study on Quality of Work Life among Employees in Cairo Amman Bank. Journal of Financial Risk Management, 6, 191-200.

https://doi.org/10.4236/jfrm.2017.62014

Received: April 24, 2017

Accepted: June 20, 2017

Published: June 23, 2017

Copyright $\odot 2017$ by author and Scientific Research Publishing Inc. This work is licensed under the Creative Commons Attribution International License (CC BY 4.0).

http://creativecommons.org/licenses/by/4.0/

\section{cc) (i) Open Access}

\begin{abstract}
Employees are considered to be the soft assets and hidden value of a company. Employees are the stimulus energy in every successful organization and therefore organizations are concerned about developing their human resources to achieve competitive advantage in the market. The productivity of an employee is not only affected by their capabilities but the environment in which they worked. High job performance is not possible unless and until employees get a better quality of work life and hence the quality of work life is indispensable in all enterprises. Taking this into cognizance, the present study has been conducted to examine the differences in the satisfaction levels of employees towards the quality of work life in Cairo Amman Bank across demographic variables. The study also investigates the impact of quality of work life on job satisfaction of employees. Data has been collected through questionnaires designed on a five-point Likert scale. Independent sample t-test, One-Way ANOVA, and multiple linear regression are the statistical tools that have been used for analysis of data. The findings highlighted that there is significant positive impact of quality of work life on satisfaction levels of employees. Notwithstanding, it has been revealed that there are significant differences in the satisfaction levels of employees towards the quality of work life across gender, education, and cadre but no significant difference has been found across age, and length of service.
\end{abstract}

\section{Keywords}

Quality of Work Life, Job Satisfaction, ANOVA, t-Test, Bank

\section{Section-A}

\subsection{Introductory Background and Literature Review}

\subsubsection{Introduction}

Employees are considered to be the soft assets and hidden value of a company 
(Daud, 2010). Employees are the stimulus energy in every successful organization and therefore organizations are concerned about developing their human resources to achieve competitive advantage in the market (Bakker, Demerouti, \& Burke, 2009). The productivity of an employee is not only affected by their capabilities but the environment in which they worked. High job performance is not possible unless and until employees get a better quality of work life and hence the quality of work life is inevitable in all organizations (Hamidi \& Mohamadi, 2012).

The quality of working life refers to the quality of the relationship between employees and total work environments of an organization (Konrad \& Mengel, 2000). It is a philosophy, a set of principles, which state that employees are the most meaningful resource in the organization and they should be dealt with dignity and respect (Mirkamali \& Narenji, 2008). The quality of work life refers to the favourableness or unfavourableness of a job environment for people (Rathi, 2009). Its purpose is to develop a work environment that is excellent for people as well as production. The better quality of work life will create involvement among the employees which ultimately helps the organization to achieve a higher level of productivity (Tabassum, Rahma, \& Jahan, 2011).

Quality of Work Life (QWL) is both a goal and an ongoing process for achieving that goal. As a goal, quality of work life is the commitment of an organization to work improvement: the creation of more involving, satisfying, and effective jobs and work environments for people at all levels of the organization. As a process, quality of work life calls for efforts to realize this goal through the active involvement of people throughout the organization (Boonrod, 2009). It is a process by which an organization responds to employee needs by developing mechanisms to allow them to share fully in making the decisions that design their lives at work. It is employee satisfaction with a variety of needs through resources, activities, and outcomes stemming from participation in the work place (Iqbal, 2013). Quality of Work Life is a continuing process, which means utilizing all resources, and especially human resources. It means developing among all members of the organization awareness and understanding of the concerns and needs of others and a willingness to be more responsive to those concerns and needs (Dargahi, Sharifi, \& Yazdi, 2007).

QWL is also a combination of strategies, procedures, and ambiance related to a workplace that altogether, enhance and sustain the employee satisfaction by aiming at improving work conditions for the employees of the organizations (Sinha, 2012). Quality of work life also includes improving the way things getting done to assure the long-term effectiveness and success of the organization. Quality of work life means changing entire organizational climate by humanizing work, individualizing the organization and changing the structural and managerial system. It seeks to create culture of work commitment in the organization which will ensure higher productivity for the company and greater job satisfaction for the employees (Mohan \& Ashok, 2011). 
QWL is a holistic program designed to improve employee's satisfaction, strengthening workplace learning and helping employees to have better manage change and transition (Gupta \& Sharma, 2011). QWL programs are another way in which organizations recognize their responsibility to develop jobs and working conditions that are excellent for people as well as for economic health of the organization. The elements in a typical QWL program include open communications, equitable reward systems, a concern for employee job security and satisfying careers, participation in decision making, job enrichment, development of employee skills, social integration, reduction of occupational stress and development of more co-operative labor-management relations (Krishnakumar \& Sugavaneswari, 2012). The current study examines the impact of quality of work life on job satisfaction of employees by taking variables namely adequate $\&$ fair compensation, safe \& healthy environment, job security, and social integration.

\subsubsection{Review of Literature}

Chan and Thomas (2007) in the research entitled, "Quality of Work Life: $A$ Study of Employees in Shanghai" examined the level of Quality of Work Life provided to employees working in eight organizations in Shanghai. Data was collected with the help of questionnaires from 319 employees and analyzed with the application of multiple regression. It was revealed that esteem need was the most important for life satisfaction among all needs. Three needs namely, economic and family, health and safety, and knowledge, were important for job satisfaction. Jamal (2009) evaluated the differences between fulltime self-employed and organizationally employed individuals in Canada and Pakistan regarding quality of work and non-work life. Job stress, burnout, job satisfaction, health problems, time spent with family and social participation were the variables of quality of work life. The findings revealed that higher job stress, burnout, and health problems were common in self-employed than the organizationally employed individuals. Toppo \& Yadav (2012) in their research paper entitled, " $A n$ Empirical Study on Employees' Quality of Work Life: A Case Study of Bokaro Steel Plant an Integrated Unit of Steel Authority of India Limited (SAIL)" explored the impact of quality of work life on employees working in Bokaro Steel Plant. It has been revealed that executives of BSL were found to be more satisfied than non-executive employees in all the taken factors of QWL working environment, employee's welfare, relationship in workplace, job factors, impact on personal life and financial factors.

\section{Section-B}

\subsection{Research Design}

\subsubsection{Objectives of the Study}

1) To investigate the impact of quality of work life on employee's job satisfaction in Cairo Amman Bank.

2) To examine the differences in the satisfaction levels of employees towards quality of work life across different demographic profiles in Cairo Amman Bank. 


\subsubsection{Hypotheses of the Study}

$\mathrm{Ho}_{1}$ : There is no significant difference in the satisfaction levels of the employees belonging to different demographic profiles towards quality of work life of employees in Cairo Amman Bank.

$\mathrm{Ho}_{1.1}$ : There is no significant difference in the satisfaction levels of the employees towards quality of work life in Cairo Amman Bank across gender.

$\mathrm{Ho}_{1.2}$ : There is no significant difference in the satisfaction levels of the employees towards quality of work life in Cairo Amman Bank across age.

$\mathrm{Ho}_{1,3}$ : There is no significant difference in the satisfaction levels of the employees towards quality of work life in Cairo Amman Bank across cadre.

$\mathrm{Ho}_{1.4}$ : There is no significant difference in the satisfaction levels of the employees towards quality of work life in Cairo Amman Bank across education.

$\mathrm{Ho}_{1.5}$ : There is no significant difference in the satisfaction levels of the employees towards quality of work life in Cairo Amman Bank across length of service.

$\mathrm{Ho}_{2}$ : There is no significant impact of quality of work life on employee's job satisfaction in Cairo Amman Bank.

\subsubsection{Research Methodology}

The population of this study consists of all employees of executive and non-executive cadre working in Cairo Amman Bank. Convenient sampling is followed meaning thereby the employees which are easily accessible have been chosen for the study. A total of 250 questionnaires were distributed to employees of executive and non-executive cadre working in Cairo Amman Bank. 85 questionnaires were rejected and 165 were accepted for analysis. The sample size of the study is 165 respondents (Table 1, Figure 1). The period of data collection was three months i.e. from January, 2017 to March, 2017. Secondary data was collected from websites, journals, articles, magazines, theses, reports and other relevant documents. So far analysis is concerned; independent sample t-test, One Way ANOVA, and multiple linear regression were used to test the hypotheses through SPSS_20 version.

\section{Section-C}

\section{Data Analysis}

\section{Reliability}

The most used test of reliability is cronbach alpha. The value of $a$ greater than or

Table 1. Sample size.

\begin{tabular}{ccc}
\hline Questionnaires & N & Percent \\
\hline Distributed & 250 & 100 \\
Rejected & 85 & 34 \\
Accepted & 165 & 66 \\
Methodology & \multicolumn{2}{c}{ Field Work } \\
& Sample Size: 165 & \\
\hline
\end{tabular}

Source: Primary Data. 
equal to 0.7 but less than 0.9 is considered good and the value of $\alpha$ greater than or equal to 0.9 is considered excellent. Table 2 highlights the reliability of all variables of the study. The value of cronbach alpha of all study variables is ranging from 0.7 to 0.9 and hence the data is reliable.

\section{Section-D}

\subsection{Hypotheses Testing}

\subsubsection{Hypothesis 1}

$\mathrm{Ho}_{1}$ : There is no significant difference in the satisfaction levels of the employees belonging to different demographic profiles towards quality of work life of employees in Cairo Amman Bank.

$\mathrm{Ha}_{1}$ : There is a significant difference in the satisfaction levels of the employees belonging to different demographic profiles towards quality of work life of employees in Cairo Amman Bank.

One way ANOVA have been applied to measure whether any difference exists between the satisfaction levels of employees working in Cairo Amman Bank across age, education, cadre, and length of service. However, independent sample $t$ test has been applied to measure whether any difference exists between the satisfaction levels of employees in Cairo Amman Bank across gender. The results of these two tests in summarized form have been shown in the above table. Table 3 highlights the mean value, standard deviation, $t$ value, $F$ value and $P$ value

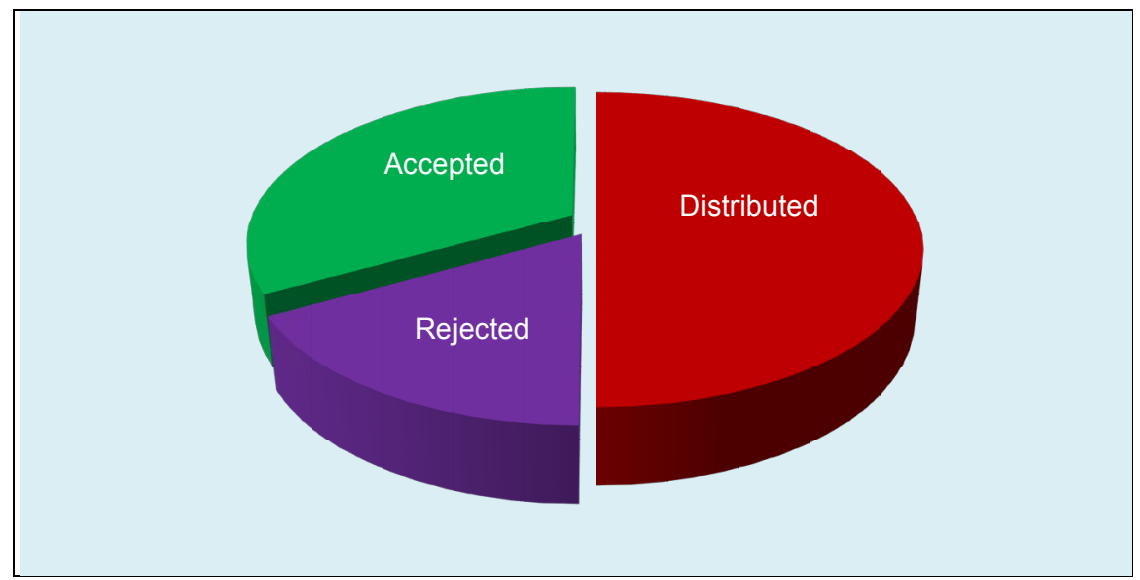

Figure 1. Questionnaires distributed, rejected, and accepted.

Table 2. Reliability analysis.

\begin{tabular}{ccc}
\hline No. & Variables & Cronbach Alpha \\
\hline $\mathbf{1}$ & Adequate \& Fair Compensation & 0.887 \\
$\mathbf{2}$ & Safe \& Healthy environment & 0.796 \\
$\mathbf{3}$ & Job Security & 0.751 \\
$\mathbf{4}$ & Social Integration & 0.889 \\
& Overall Reliability: $\mathbf{0 . 8 4 6}$ & \\
\hline
\end{tabular}

Source: Output of SPSS_20. 
Table 3. Shows the Mean, SD, and P-Value for each attributes.

\begin{tabular}{|c|c|c|c|c|c|c|c|}
\hline S. No & Attributes & Category & $\mathrm{N}$ & Mean & SD & $t / F$ & P-Value \\
\hline \multirow{2}{*}{1} & \multirow{2}{*}{ Gender } & Male & 115 & 3.311 & 1.110 & \multirow{2}{*}{2.664} & \multirow{2}{*}{0.0021} \\
\hline & & Female & 50 & 3.009 & 1.321 & & \\
\hline \multirow{4}{*}{2} & \multirow{4}{*}{ Age } & 25 - 35 Years & 31 & 3.691 & 1.445 & \multirow{4}{*}{23.415} & \multirow{4}{*}{0.669} \\
\hline & & 36 - 45 Years & 58 & 3.443 & 1.181 & & \\
\hline & & 46 - 55 Years & 61 & 3.227 & 1.064 & & \\
\hline & & Above 55 Years & 15 & 3.854 & 1.224 & & \\
\hline \multirow{4}{*}{3} & \multirow{4}{*}{ Education } & Under Graduates & 11 & 3.041 & 1.331 & \multirow{4}{*}{18.644} & \multirow{4}{*}{0.000} \\
\hline & & Graduates & 65 & 3.336 & 1.247 & & \\
\hline & & Post Graduates & 59 & 3.297 & 1.119 & & \\
\hline & & Others & 30 & 4.012 & 1.008 & & \\
\hline \multirow{2}{*}{4} & \multirow{2}{*}{ Cadre } & Executive & 102 & 3.311 & 1.550 & \multirow{2}{*}{2.664} & \multirow{2}{*}{0.0044} \\
\hline & & Non-Executive & 63 & 3.009 & 1.689 & & \\
\hline \multirow{5}{*}{5} & \multirow{5}{*}{ Length of Service } & $0-5$ Years & 14 & 4.115 & 1.496 & \multirow{5}{*}{31.740} & \multirow{5}{*}{0.855} \\
\hline & & $5-10$ Years & 54 & 4.057 & 0.997 & & \\
\hline & & $10-15$ Years & 42 & 4.123 & 0.887 & & \\
\hline & & $15-20$ Years & 38 & 3.997 & 1.045 & & \\
\hline & & Above 20 Years & 17 & 4.304 & 1.066 & & \\
\hline
\end{tabular}

Source: Output of SPSS_20.

on all demographic attributes. Firstly, the $\mathrm{p}$ value on demographic variable gender is less than 0.05 , so null hypothesis is rejected and hence it can be said that there is a significant difference between the satisfaction levels of employees in Cairo Amman Bank across gender. Secondly, the p value on demographic variable age is more than 0.05 , so null hypothesis is accepted and hence it can be said that is no significant difference between the satisfaction levels of employees in Cairo Amman Bank across age. Thirdly, the $\mathrm{p}$ value on demographic variable education is less than 0.05 , so null hypothesis is rejected and hence it can be said that there is a significant difference between the satisfaction levels of employees in Cairo Amman Bank across education. Fourthly, the p value on demographic variable cadre is less than 0.05 , so null hypothesis is rejected and hence it can be said that there is a significant difference between the satisfaction levels of employees in Cairo Amman Bank across cadre. Fifthly, the $\mathrm{p}$ value on demographic variable length of service is more than 0.05 , so null hypothesis is accepted and hence it can be said that is no significant difference between the satisfaction levels of employees in Cairo Amman Bank across length of service.

\subsubsection{Hypothesis 2}

$\mathrm{Ho}_{2}$ : There is no significant impact of quality of work life on employee's job satisfaction in Cairo Amman Bank.

$\mathrm{Ha}_{2}$ : There is a significant impact of quality of work life on employee's job satisfaction in Cairo Amman Bank.

Multiple linear regression has been applied to examine the impact of quality of work life on employee's job satisfaction in Cairo Amman Bank. Table 4 shows the multiple linear regression analysis of quality of work life and job satisfaction. Adjusted R square shows the amount of variation in one variable (job 
satisfaction) that is accounted by another variable (quality of work life). The above table shows the value of adjusted $\mathrm{R}$ square is 0.652 which means 65.2 percent variation in job satisfaction is explained by the quality of work life and the rest of the variation $\left(1-R^{2}\right)$ is an unexplained variation in job satisfaction due to variables that has not been considered in this model.

Table 5 shows the results of ANOVA. It assesses the overall significance of the model. The overall model is significant because the significant value is 0.000 which is less than 0.05 at 95 percent confidence interval. Hence, the model construct is validated.

Table 6 shows the results of multiple linear regression analysis. Employee's job satisfaction is dependent variable whereas adequate $\&$ fair compensation, safe \& healthy environment, job security, social integration are independent variables. Firstly, adequate $\&$ fair compensation has positive impact on job satisfaction since the unstandardized beta coefficient is 0.2880 . It indicates that for every one unit change in adequate \& fair compensation, there will be 0.288 unit change in job satisfaction. However, its regression coefficient is statistically significant at $5 \%$ level of significance $(P<0.05)$. Secondly, the unstandardized beta coefficient of safe $\&$ healthy environment is 0.3176 which indicates that one unit change in safe \& healthy environment will bring 0.31 unit change in job satisfaction. Further, its regression coefficient is statistically significant at $5 \%$ level of significance $(\mathrm{P}<0.05)$. Thirdly, job security has significant positive relationship

Table 4. Model summary-quality of work life.

\begin{tabular}{cccccc}
\hline Model & R & R Square & Adjusted R Square & Standard Error & Durbin Watson \\
\hline 1 & 0.824 & 0.679 & 0.652 & 1.8961 & 1.9067 \\
\hline
\end{tabular}

Predictors: (Constant), Quality of Work Life; Source: Output of SPSS_20.

Table 5. ANOVA-model fitness.

\begin{tabular}{cccccc}
\hline Model-1 & Sum of Squares & df & Mean Square & F Value & P Value \\
\hline Regression & 111.157 & 1 & 111.157 & 48.392 & $0.000^{\mathrm{a}}$ \\
Residual & 374.507 & 163 & 2.297 & & \\
Total & 485.665 & 164 & & & \\
\hline
\end{tabular}

Predictors: (Constant), Quality of Work Life; Dependent Variable: Job Satisfaction; Source: Output of SPSS_20.

Table 6. Regression coefficients.

\begin{tabular}{lcccc}
\hline \multicolumn{1}{c}{ Independent Variables } & $\begin{array}{c}\text { Regression } \\
\text { Coefficients }\end{array}$ & $\begin{array}{c}\text { Standard } \\
\text { Error }\end{array}$ & $\begin{array}{c}\text { T } \\
\text { Value }\end{array}$ & $\begin{array}{c}\text { P } \\
\text { Value }\end{array}$ \\
\hline (Constant) & 0.8571 & 0.6742 & -1.561 & 0.0000 \\
Adequate \& Fair Compensation & 0.2880 & 0.8424 & 4.874 & 0.0004 \\
Safe \& Healthy environment & 0.3176 & 0.5327 & -9.349 & 0.0001 \\
Job Security & 0.2408 & 0.7508 & 11.226 & 0.0063 \\
Social Integration & 0.3095 & 0.8372 & -5.968 & 0.0031 \\
\hline
\end{tabular}

Dependent Variable: Job Satisfaction; Source: Output of SPSS_20. 
with Job satisfaction at $5 \%$ level of significance. The unstandardized beta coefficient value of job security is 0.2408 which highlights that for one unit change in job security, there will 0.24 unit changes in job satisfaction. The regression coefficient of profitability is statistically significant at 5\% level of significance $(\mathrm{P}<$ 0.05). Fourthly, social integration has significant positive relationship with Job satisfaction at $5 \%$ level of significance. The unstandardized beta coefficient of social integration is 0.3095 which highlights that for one unit change in social integration, there is 0.30 unit change in job satisfaction. The regression coefficient of social integration is statistically significant at $5 \%$ level of significance ( $P$ $<0.05)$. Hence, it can be said that there is significant impact of quality of work life on employee's job satisfaction in Cairo Amman Bank.

Table 7 exhibits the results of hypotheses tested in the current study. The hypotheses $1.1,1.3$, and 1.4 have been rejected which means that there is a significant difference in the satisfaction levels of the employees towards quality of work life in Cairo Amman Bank across gender, education, and cadre. However, 1.2 and 1.5 have been accepted meaning thereby there is no significant difference in the satisfaction levels of the employees towards quality of work life in Cairo Amman Bank across age and length of service. So far hypothesis 2 is concerned, it is rejected.

\section{Conclusion}

Quality of work life means changing entire organizational climate by humanizing work, individualizing the organization and changing the structural and managerial system. It seeks to create culture of work commitment in the organization which will ensure higher productivity for the company and greater job satisfaction for the employees. High job performance is not possible unless and

Table 7. Results of hypotheses tested.

\begin{tabular}{clc}
\hline No. & \multicolumn{1}{c}{ Hypotheses } & Results \\
\hline 1 & $\begin{array}{l}\text { There is no significant difference in the satisfaction levels of the employees } \\
\text { belonging to different demographic profiles towards quality of work life of } \\
\text { employees in Cairo Amman Bank. }\end{array}$ & - \\
1.1 & $\begin{array}{l}\text { There is no significant difference in the satisfaction levels of the employees } \\
\text { towards quality of work life in Cairo Amman Bank across gender. }\end{array}$ & Rejected \\
1.2 & $\begin{array}{l}\text { There is no significant difference in the satisfaction levels of the employees } \\
\text { towards quality of work life in Cairo Amman Bank across age. }\end{array}$ & Accepted \\
1.3 & $\begin{array}{l}\text { There is no significant difference in the satisfaction levels of the employees } \\
\text { towards quality of work life in Cairo Amman Bank across education. }\end{array}$ & Rejected \\
1.4 & $\begin{array}{l}\text { There is no significant difference in the satisfaction levels of the employees } \\
\text { towards quality of work life in Cairo Amman Bank across cadre. }\end{array}$ & Rejected \\
1.5 & $\begin{array}{l}\text { There is no significant difference in the satisfaction levels of the employees } \\
\text { towards quality of work life in Cairo Amman Bank across length of service. }\end{array}$ & Accepted \\
& $\begin{array}{l}\text { There is no significant impact of quality of work life on employee's job } \\
\text { satisfaction in Cairo Amman Bank. }\end{array}$ & Rejected \\
\hline
\end{tabular}

Source: Based on Hypotheses Tested. 
until employees get better quality of work life. In this study, an attempt has been made by the researcher to examine the differences in the satisfaction levels of employees towards quality of work life in Cairo Amman Bank across demographic variables namely age, gender, education, cadre, and length of service. Data has been collected through questionnaires designed on five point Likert scale from 165 respondents. The findings highlighted that there is significant difference in the satisfaction levels of employees towards the quality of work life across gender, cadre and education but significant differences have not revealed across age, length of service. Nonetheless, the research further highlighted that there is significant positive impact of quality of work life on satisfaction levels of employees.

\section{References}

Bakker, A., Demerouti, E., \& Burke, R. (2009). Workaholism and Relationship Quality: A Spillover-Crossover Perspective. Journal of Occupational Health Psychology, 14, 23-33. https://doi.org/10.1037/a0013290

Boonrod, W. (2009). Quality of Working Life: Perceptions of Professional Nurses at Phramongkutklao Hospital. Journal of the Medical Association of Thailand, 92, 7-15.

Chan, K. W., \& Thomas, W. (2007). Quality of Work Life: A Study of Employees in Shanghai. Asia Pacific Business Review, 13, 501-517. https://doi.org/10.1080/13602380701250681

Dargahi, H., Sharifi, \& Yazdi, M. K. (2007). Quality of Work Life in TUMS Hospital Clinical Lab Employees. Pakistan Journal of Medical Sciences, 23, 630-633.

Daud, N. (2010). Investigating the Relationship between Quality of Work Life and Organizational Commitment amongst Employees in Malaysian Firms. International Journal of Business and Management, 5, 75-82. https://doi.org/10.5539/ijbm.v5n10p75

Gupta, M., \& Sharma, P. (2011). Factor Credentials Boosting Quality of Work Life of BSNL Employees in Jammu Region. Asia Pacific Journal of Research in Business Management, 2, 79-89.

Hamidi, F., \& Mohamadi, B. (2012). Teachers' Quality of Work Life in Secondary Schools. International Journal of Vocational and Technical Education, 4, 1-5.

Iqbal, K. (2013). Determinants of Organizational Justice and Its Impact on Job Satisfaction. A Pakistan Base Survey. International Review of Management and Business Research, 2, 48-56.

Jamal, M. (2009). Self-Employment and Quality of Work and Non-Work Life: A Study in Cross-Cultural Management. Journal of Small Business and Entrepreneurship, 22, 8995. https://doi.org/10.1080/08276331.2009.10593465

Konrad, A. M., \& Mengel, R. (2000). The Impact of Work Life Program on Firm Productivity. Strategic Management Journal, 21, 1225-1237. https://doi.org/10.1002/1097-0266(200012)21:12<1225::AID-SMJ135>3.0.CO;2-3

Krishnakumar, K., \& Sugavaneswari, P. M. (2012). Quality of Work Life-A Phenomenon for Organizational Success. International Journal of Multidisciplinary Management Studies, 2, 220-230.

Mirkamali, S. M., \& Narenji, S. F. (2008). Investigating the Relationship between Quality of Work Life and Job Satisfaction among Faculty Members of Tehran and Sharif. Journal of Research and Planning in Higher Education, 48, 65-75.

Mohan, P., \& Ashok, G. (2011). Measuring of Quality of Work Life in Textile Indus- 
tries-An Integration of Conceptual Relationship with Productivity. International Journal of Research in Commerce and Management, 2, 67-70.

Rathi, N. (2009). Relationship of Quality of Work Life with Employee's Psychological Well-Being. Journal of Business Insights \& Transformation, 54, 53-60.

Sinha, C. (2012). Factors Affecting Quality of Work Life: Empirical Evidence from Indian Organizations. Australian Journal of Business and Management Research, 1, 31-40.

Tabassum, A., Rahma, T., \& Jahan, K. (2011). Quality of Work Life among Male and Female Employees of Private Commercial Banks in Bangladesh. International Journal of Economics and Management, 5, 266-282.

Toppo, G., \& Yadav, P. (2012). An Empirical Study on Employees' Quality of Work Life: A Case Study of Bokaro Steel Plant an Integrated Unit of Steel Authority of India Limited (SAIL). International Research Journal of India, 11, 45-49.

\section{Submit or recommend next manuscript to SCIRP and we will provide best} service for you:

Accepting pre-submission inquiries through Email, Facebook, LinkedIn, Twitter, etc. A wide selection of journals (inclusive of 9 subjects, more than 200 journals)

Providing 24-hour high-quality service

User-friendly online submission system

Fair and swift peer-review system

Efficient typesetting and proofreading procedure

Display of the result of downloads and visits, as well as the number of cited articles

Maximum dissemination of your research work

Submit your manuscript at: http://papersubmission.scirp.org/

Or contact jfrm@scirp.org 